\title{
OmpR, a response regulator of the two-component signal transduction pathway, influences inv gene expression in Yersinia enterocolitica 09
}

\author{
Marta Brzóstkowska, Adrianna Raczkowska and Katarzyna Brzostek* \\ Department of Applied Microbiology, Institute of Microbiology, Faculty of Biology, University of Warsaw, Warsaw, Poland
}

Edited by:

Matthew Francis, Umeå University,

Sweden

\section{Reviewed by:}

Matthew B. Lawrenz, University of Louisville School of Medicine, USA Kimberly Walker, University of North Carolina at Chapel Hill, USA

\section{${ }^{*}$ Correspondence:}

Katarzyna Brzostek, Department of Applied Microbiology, Institute of

Microbiology, University of Warsaw,

Miecznikowa 1, 02-096 Warsaw,

Poland.

e-mail: kbrzostek@biol.uw.edu
The environmental control of invasin (inv) expression in Yersinia enterocolitica is mediated by a regulatory network composed of negative and positive regulators of inv gene transcription. Previously, we demonstrated that $\mathrm{OmpR}$, a response regulator of the two-component signal transduction pathway EnvZ/OmpR, negatively regulates inv gene expression in $Y$. enterocolitica $\mathrm{O} 9$ by direct interaction with the inv promoter region. This study was undertaken to clarify the role of $O m p R$ in the inv regulatory circuit in which RovA protein has been shown to positively regulate inv transcription. Using ompR, rovA, and ompR rovA Y. enterocolitica mutant backgrounds we showed that the inhibitory effect of OmpR on inv transcription may be observed only when RovA is present/active in $Y$. enterocolitica cells. To extend our research on inv regulation we examined the effect of OmpR on rovA gene expression. Analysis of rovA-lacZ transcriptional fusion in $Y$. enterocolitica wild-type and ompR background indicated that $\mathrm{OmpR}$ does not influence rovA expression. Thus, our results indicate that OmpR influences inv expression directly via binding to the inv promoter, but not through modulation of rovA expression.

Keywords: invasin, OmpR regulator, RovA regulator, signal transduction pathway, Yersinia enterocolitica

\section{INTRODUCTION}

Yersinia enterocolitica is a human gastrointestinal pathogen that is able to exist free-living in the environment. Survival in the different ecological niches requires adaptation of pathogen to the changing physico-chemical conditions, such as temperature, $\mathrm{pH}$, osmolarity, accessibility of nutrients, viscosity of the medium, etc. (Straley and Perry, 1995; Bottone, 1997).

The molecular mechanisms enabling bacterial response to signals coming from the external environment are very complex and involve two-component transduction systems (TCSs) (Stock et al., 1989; Hoch and Silhavy, 1995). TCSs play a significant regulatory role in the transduction of environmental signals in various species of bacteria, including the genus Yersinia. Based on the entire genome sequence of Y. enterocolitica and theoretical relationships, a number of putative TCSs of Y. enterocolitica have been identified, however, the function of most of them still requires experimental verification (Marceau, 2005). The in silico analysis of the genome of Yersinia pestis (strain CO92) has revealed 29 putative TCSs (including 4 pseudogenes), whereas the genome of the enteropathogenic Yersinia pseudotuberculosis appears to encode 24 complete TCSs (Flamez et al., 2008; O'Loughlin et al., 2010).

One of the most extensively studied TCSs is the EnvZ/OmpR regulatory system of non-pathogenic Escherichia coli (E. coli) K-12 that controls the expression levels of outer membrane porin proteins $\mathrm{OmpF}$ and $\mathrm{OmpC}$ in response to changes in the osmolarity of the environment (Russo and Silhavy, 1991; Cai and Inouye, 2002). The basic components of EnvZ/OmpR transduction pathway are a dimeric histidine kinase EnvZ, serving as a signal sensor, and its cognate response regulator $\mathrm{OmpR}$, a cytoplasmic winged helix transcription factor (Forst and Roberts, 1994; Kenney, 2002). Upon sensing a signal, the EnvZ autophosphorylates and then the phosphate group of EnvZ-P is transferred to OmpR to form phosphorylated OmpR (OmpR-P). Since EnvZ can act also as a phosphatase, it is able to remove the phosphoryl group from the phosphorylated/activated form of OmpR. In response to environmental changes, the ratio of the kinase to the phosphatase activity of EnvZ modulates the cellular level of OmpR-P (Yoshida et al., 2002; Qin et al., 2003). OmpR-P serves as a transcription factor which, by binding to promoter regions of target genes regulates their expression. OmpR protein has been revealed as a global transcriptional regulator implicated in the control of various cellular processes and functions in many Gramnegative bacteria (Gibson et al., 1987; Higashitani et al., 1993; Shin and Park, 1995; Jubelin et al., 2005).

It has also been shown that, OmpR plays a significant role in controlling the expression of virulence factors of bacterial pathogens (Dorman et al., 1989; Bernardini et al., 1990; Bang et al., 2000; Lee et al., 2000; Brzostek et al., 2007). In yersiniae, the mechanism of TCS action revealed in biochemical and genetic analyses seems to follow the same pattern as observed for EnvZ/OmpR in E. coli. Moreover, a recent comparative transcriptome analysis of $Y$. pestis identified a set of 224 genes affected by the $\operatorname{ompR}$ mutation leading to detailed studies of the OmpRdependent expression of $\operatorname{mp}$ C, F, X, and $\operatorname{omp} R$ (Gao et al., 2011). It also appears that $\mathrm{OmpR}$ could operate as a global regulatory protein in Y. enterocolitica cells. The involvement of EnvZ/OmpR system of $Y$. enterocolitica in the regulation of porin synthesis was 
described (Brzostek et al., 1989; Brzostek and Raczkowska, 2007). The discovery that the $\operatorname{mp} R$ mutant of Y. enterocolitica serotype $\mathrm{O} 8$ is attenuated in the murine yersiniosis model (Dorrell et al., 1998) was an incentive to investigate the putative correlation between the EnvZ/OmpR functions and the expression of virulence genes in pathogenic Y. enterocolitica serotype O9 (Brzostek and Raczkowska, 2003). The in vitro analysis of the growth and survival of $Y$. enterocolitica $\mathrm{O} 9$ cells lacking the OmpR protein, subjected to various environmental stresses, revealed that OmpR is involved in the adaptation of Y. enterocolitica to high osmolarity, oxidative stress and low $\mathrm{pH}$. Recent studies provided evidence that, OmpR is involved in the control of motility by positive regulation of flagellar master operon flhDC in both $Y$. enterocolitica O9 and Y. pseudotuberculosis (Hu et al., 2009b; Raczkowska et al., $2011 b$ ). This finding is in contrast to the negative role the regulator was shown to play in E. coli (Shin and Park, 1995). Lastly, it has been shown that OmpR-dependent regulation of biofilm is an additional aspect of $\mathrm{OmpR}$ regulatory function in Y. enterocolitica O9 (Raczkowska et al., 2011c).

In addition, we demonstrated previously that OmpR negatively regulates invasin (inv) gene expression in Y. enterocolitica O9 by direct interaction with the inv promoter region (Brzostek et al., 2007). inv is an important adhesion/invasion factor localized in the outer membrane of $Y$. enterocolitica and Y. pseudotuberculosis, which is responsible for the ability of enteropathogenic Yersinia to penetrate the epithelium of the host intestines (Grutzkau et al., 1990; Pepe and Miller, 1993; Isberg and Van Nhieu, 1995; Dersch and Isberg, 2000; Nagel et al., 2001). Various environmental factors such as temperature, growth phase, nutrients, $\mathrm{pH}$, and osmolarity influence the inv gene transcription levels, thus modulating the expression of inv. The highest levels of inv expression in Y. enterocolitica O8 and $Y$. pseudotuberculosis were observed in the stationary phase cultures incubated at moderate temperature $\left(23-26^{\circ} \mathrm{C}\right)$ (Pepe et al., 1994; Nagel et al., 2001). However, recent studies of the effect of temperature and growth phase on the inv gene expression using the luxCDABE reporter system showed differences in the inv promoter activity between strains of $Y$. enterocolitica serotype $\mathrm{O} 8$ and O9 (Trček et al., 2010).

Genetic and physiological studies have revealed that numerous regulatory proteins are involved in the process of modulation of inv expression in response to environmental cues. The thermoregulation of inv gene expression in Y. enterocolitica $\mathrm{O} 8$ and Y. pseudotuberculosis seems to involve at least three regulatory proteins, namely RovA, H-NS, and YmoA (Ellison et al., 2003; Heroven et al., 2004; Tran et al., 2005; Ellison and Miller, 2006b). RovA, a member of the large MarR/SlyA family of transcriptional regulators identified in Enterobacteriaceae, acts as a positive regulator of inv expression at low temperature $\left(23-26^{\circ} \mathrm{C}\right)$ in both enteropathogenic yersiniae (Revell and Miller, 2000; Nagel et al., 2001; Ellison and Miller, 2006a). Moreover, RovA protein has been indicated as an important factor involved directly or indirectly in the transcriptional regulation of many other Yersinia genes, some of which have been linked to virulence (Ellison et al., 2004; Cathelyn et al., 2006, 2007). H-NS is a small nucleoid-associated protein identified as a repressor of inv expression (Atlung and Ingmer, 1997; Heroven et al.,
2004; Ellison and Miller, 2006b). In Y. enterocolitica, repression of inv seems to be mediated not solely by H-NS. YmoA, a histone-like protein acts together with $\mathrm{H}$-NS inhibiting the expression of inv gene (Ellison et al., 2003). Following the upshift of temperature to $37^{\circ} \mathrm{C}$, H-NS and YmoA are believed to form a transcriptional repression complex on the inv promoter, which becomes very effective in competing with the RovA protein for binding to the inv promoter region. At $26^{\circ} \mathrm{C}$, higher levels of cellular RovA block the inv promoter binding sites, which antagonizes H-NS/YmoA-mediated repression leading to elevated inv expression (Ellison et al., 2003; Ellison and Miller, 2006b). Thermoregulation of RovA expression has been found to be a very complex process involving transcriptional and post-transcriptional mechanisms. It has been recently shown that the temperature shift from $25^{\circ} \mathrm{C}$ to $37^{\circ} \mathrm{C}$ not only affects rovA expression, but also RovA DNA-binding activity and renders the RovA protein more susceptible to degradation by the Lon and ClpP proteases (Herbst et al., 2009; Uliczka et al., 2011). Apart from the well-studied RovA and H-NS/YmoA interactions with inv promoter region in both enteropathogenic yersiniae, it has been also reported that the transcriptional regulator CpxR of the Cpx extracytoplasmic-stress-responsive TCS of $Y$. pseudotuberculosis modulates inv expression by direct negative effect on both inv and rovA transcription (Carlsson et al., 2007; Liu et al., 2011).

The results of our previous study revealed the involvement of the transcriptional regulator OmpR in the negative regulation of the inv gene in Y. enterocolitica O9 (Brzostek et al., 2007). Recently, the osmoregulation of inv expression was found to be a multifaceted process involving both OmpR-dependent and -independent mechanisms (Raczkowska et al., 2011a).

The aim of the present study was to more precisely define the function of $\mathrm{OmpR}$ in the transcriptional response of the inv gene. In light of the evidence for the participation of RovA in positive regulation of inv expression, we focused on the role of OmpR in the regulatory OmpR/RovA interplay.

\section{MATERIALS AND METHODS BACTERIAL STRAINS, PLASMIDS, AND GROWTH CONDITIONS}

The bacterial strains and plasmids used in this study are listed in Table 1. Y. enterocolitica strains were cultivated in Luria-Bertani (LB) medium at $25^{\circ} \mathrm{C}$ or $37^{\circ} \mathrm{C}$ with aeration to mid-log-phase or to early stationary growth phase.

To monitor the influence of $\mathrm{pH}$ of the growth medium, an overnight culture was grown and variation of the $\mathrm{pH}$ was achieved by buffering the growth medium with MOPS [3-(N-morpholino) propanesulfonic acid- $\mathrm{pH}$ 7.0, 7.5, 8.0, 8.5], MES [2-(N-morpholino)ethanesulfonic acid- $\mathrm{pH}$ 5.5, 6.0, 6.5], or homoPIPES [homopiperazine- $N, N^{\prime}$-bis(2-ethanesulfonic acid) $-\mathrm{pH} 5.0$ ] at $0.1 \mathrm{M}$. Where appropriate, antibiotics were added to media at the following concentrations: chloramphenicol, $25 \mu \mathrm{g} \mathrm{ml}^{-1}$; kanamycin, $50 \mu \mathrm{g} \mathrm{ml}^{-1}$; nalidixic acid, $20 \mu \mathrm{g}$ $\mathrm{ml}^{-1}$; tetracycline $12.5 \mu \mathrm{g} \mathrm{ml}^{-1}$.

\section{DNA TECHNIQUES}

DNA manipulations, such as restriction digestion, ligation, transformation, and conjugation were performed using standard 
Table 1 | Strains and plasmids used.

\begin{tabular}{|c|c|c|}
\hline Strain or plasmid & Description & Reference or source \\
\hline \multicolumn{3}{|c|}{ Y. enterocolitica 09} \\
\hline Ye9 & $\mathrm{pYV}^{+}$, wild type & Laboratory collection \\
\hline AR4 & $\mathrm{pYV}^{+}, \mathrm{Nal}^{\mathrm{R}}, \Delta o m p R:: k a n$ & Brzostek and Raczkowska, 2003 \\
\hline AS3 & $\mathrm{pYV}^{+}, \mathrm{Nal}^{\mathrm{R}}$, rovA::pEP185.2, $\mathrm{Cm}^{\mathrm{R}}$ & This work \\
\hline $\mathrm{AC} 1$ & $\mathrm{pYV}^{+}, \mathrm{Nal}^{\mathrm{R}}, \Delta$ ompR::kan, rovA::pEP185.2, $\mathrm{Cm}^{R}$ & This work \\
\hline ARR8 & $\mathrm{pYV}^{+}, \mathrm{Nal}^{\mathrm{R}}, \Delta o m p R:: k a n, \operatorname{rov} A:: \operatorname{lac} Z Y A, \mathrm{Cm}^{\mathrm{R}}$ & This work \\
\hline \multicolumn{3}{|l|}{ E. coli } \\
\hline S17-1 $\lambda$ pir & pro thi recA hsdR514 $\left(\mathrm{R}^{+} \mathrm{M}^{-}\right)$pir RP4 2-Tc::Mu-Kn::Tn7 $\left(\operatorname{Tp}^{\mathrm{R}} \mathrm{Str}^{\mathrm{R}}\right)$ & Simon et al., 1983 \\
\hline Top10 F' & 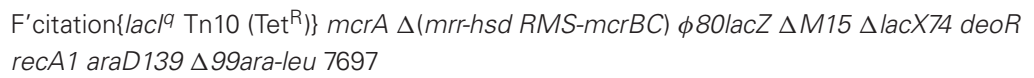 & Invitrogen \\
\hline ER3 & pEP185.2 with Xbal/Smal fragment (249 bp) of rovA, $\mathrm{Cm}^{R}$ & This work \\
\hline pFR1 & pFUSE with Xbal/Smal fragment (412 bp) of rovA, $\mathrm{Cm}^{R}$ & This work \\
\hline pET28a & expression vector with $6 \mathrm{His}$-tag coding sequence, $\mathrm{Km}^{R}$ & Novagen \\
\hline ETR1 & pET28a with $432 \mathrm{bp}$ fragment representing the entire rov $A$ coding sequence, $\mathrm{Km}^{\mathrm{R}}$ & This work \\
\hline pETRlac & pETR1 containing BgllI/Xbal DNA fragment with lac promoter, $\mathrm{Km}^{R}$ & This work \\
\hline
\end{tabular}

protocols (Sambrook et al., 1989). Plasmid and chromosomal DNA were purified using Invitrogen kits. DNA fragments were amplified by PCR using Taq DNA polymerase (Invitrogen) and oligonucleotide primers. PCR products were purified directly using the PureLink PCR purification kit (Invitrogen), or following agarose gel electrophoresis, with the PureLink Gel extraction kit (Invitrogen).

\section{B-GALACTOSIDASE ASSAYS}

$\beta$-Galactosidase activities were assayed by the method of Miller (1972) with ONPG (o-nitrophenyl- $\beta$-galactopyranoside) as a substrate. Routinely, triplicate cultures were grown for each assay and the assays were repeated at least twice.

\section{CONSTRUCTION OF $\boldsymbol{Y}$. enterocolitica rovA INSERTION MUTANT}

Gene inactivation in $Y$. enterocolitica strains was performed by plasmid insertion through homologous recombination using the conjugative suicide vector pEP185.2 (Kinder et al., 1993). A 249bp intragenic fragment of rovA was amplified using the primers rovA1 (5'-TGTCTAGAGGTATGGCAGGACAAGGTGT-3') and rovA249 (5'-TGCCCGGGAAGCCAGAGATCGCAATGAT-3 $\left.{ }^{\prime}\right)$. The DNA fragment was subcloned into the pDrive cloning vector (Qiagen), then excised with restriction enzymes XbaI and SmaI and subsequently ligated with XbaI/SmaI-digested pEP185.2. The resulting construct, pER3, was transferred from E. coli S17-1 $\lambda$ pir to $Y$. enterocolitica strains AR4 and/or Ye9N by biparental conjugation. Strains harboring plasmids integrated into the chromosome were recovered by selecting for $\mathrm{Cm}^{\mathrm{r}}$. The insertion mutant strains obtained by this strategy were designated AS3 $(\operatorname{rov} A)$ and $\mathrm{ACl}(\operatorname{ompR}, \operatorname{rov} A)$. Correct integration at the rovA locus was confirmed by PCR with one primer located upstream of the homologous region used for recombination and the other within the chloramphenicol resistance cassette of the suicide vector (data not shown).

\section{CONSTRUCTION OF pETR1 AND pETRIac PLASMIDS}

To create pETR1, a 432-bp fragment representing the entire rovA coding sequence was amplified using primers RovApET1 (5'-CATGCCATGGATGGAATCGACATTAGGATCTGA-3') and RovApET2 (5'-CCGCTCGAGCTTACTTTGTAGTTGAATAA TGTTTCTCTC- $\left.3^{\prime}\right)$. The PCR product was digested with XhoI and NcoI and ligated with XhoI/NcoI-cleaved vector pET28a. The resulting vector expresses RovA fusion protein with an amino-terminal $\mathrm{His}_{6}$ extension.

To obtain pETRlac a 423-bp DNA fragment containing the lac promoter was amplified by PCR with primers Lac1B (5' -TGAGATCTTATGGAAAAACGCCAGCAAC- $\left.3^{\prime}\right)$ and Lac423X (5'-TGTCTAGATGGCGTAATCATGGTCATAGC-3') using pBluescript SK II $(+)$ as a template. The PCR product was digested with BglII and $\mathrm{XbaI}$ and cloned into the BglII/XbaI site of pETR1. The resulting vector expresses the RovA protein under the transcriptional control of the lac promoter instead of the excised T7 promoter. To complement the rovA mutation, the pETRlac plasmid was introduced into Y. enterocolitica strain AS3 by electroporation. Strains harboring the plasmid were recovered by selecting for $\mathrm{Km}^{\mathrm{r}}$.

\section{SEMI-QUANTITATIVE REVERSE TRANSCRIPTION (RT)-PCR GENE EXPRESSION ANALYSIS}

Total RNA was extracted from strains of Y. enterocolitica grown under different conditions using a GF-1 Nucleic Acid Extraction Kit (Vivantis). This RNA was treated with RNase-free DNase I 
(Invitrogen) and quantified by spectrophotometry (absorbance at $260 \mathrm{~nm}$ ). cDNA was synthesized using the SuperScript III FirstStrand Synthesis System for RT-PCR (Invitrogen). To exclude the possibility of DNA contamination, minus-RT controls (without the reverse transcriptase) were prepared from RNA samples. The cDNA concentration for expression analysis was normalized using PCR with primers amplifying a 211-bp fragment of the constitutively expressed Y. enterocolitica 16S rRNA gene (forward primer F16SRT 5'-TACGCATTTCACCGCTACAC-3'; reverse primer R16SRT 5'-CAGAAGAAGCACCGGCTAAC-3'). Primer pairs were designed to amplify 384-bp inv fragment (FinvRT $5^{\prime}$-ACCCTGTACCCAATACCGAAG- $3^{\prime}$ and RinvRT 5'-CTCG ATCAGCGCAGTAAAATC-3') and $239 \mathrm{bp}$ ompR fragment (FompR250 5'-GCTCTAGAGCCAAGGGTGAAGAAGTTGA-3' and RompR489 5'-TCCCCCGGGGCTGGTCAGTGGCAT AGGTT-3'). The primers were used with different cDNA preparations in PCRs to semi-quantitatively compare the expression level of these genes. The number of cycles used varied according to the abundance of the various mRNAs to ensure that the comparisons were performed in the linear range of amplification: 10-16 cycles for the 16S rRNA gene, 23-28 for inv and 23-25 for $\operatorname{ompR}$. The separately amplified products of $16 \mathrm{~S}$ rRNA gene and the analyzed genes (inv or ompR) were mixed and loaded together onto $2 \%$ TAE agarose gels, separated by electrophoresis and stained with ethidium bromide. Band intensities were quantified using ImageMaster VDS (Amersham Pharmacia Biotech) with Quantity One software (Bio-Rad). RT-PCR values are presented as a ratio of the specified gene signal divided by the $16 \mathrm{~S}$ rRNA signal. Statistical significance was calculated using ANOVA and Tukey's post-hoc multiple mean comparison test. Tukey's test compares each RT-PCR signals mean in a pairwise manner. Statistical significance was accepted at $P<0.05$.

\section{WESTERN IMMUNOBLOTTING}

The expression of OmpR protein in Y. enterocolitica cells was evaluated by Western blot analysis. Equal numbers of bacterial cells, grown under different conditions, were resuspended in $10 \mathrm{mM}$ phosphate buffer ( $\mathrm{pH} 8.0$ ) containing $1 \mathrm{mM}$ phenylmethylsulfonyl fluoride (PMSF) and sonicated. After centrifugation of the cell extracts $\left(15,500 \times \mathrm{g}, 30 \mathrm{~min}, 4^{\circ} \mathrm{C}\right)$ the supernatant fractions were collected and the total protein in each sample was quantified (Bio-Rad Protein Assay). Equal amounts $(8 \mu \mathrm{g})$ of total protein from each sample were mixed with $2 \times$ sodium dodecyl sulfate (SDS)-electrophoresis loading buffer and boiled for $5 \mathrm{~min}$. Electrophoresis of samples was carried out on SDS-urea polyacrylamide gels ( $12 \%$ polyacrylamide, $6 \mathrm{M}$ urea). The gels were then blotted onto Immun-blot PVDF membrane (Bio-Rad) using a semi-dry transfer unit (Hoeffer Scientific Instruments) for $1 \mathrm{~h}$ at $50 \mathrm{~V}$ following the procedure of Towbin et al. (1979). The OmpR protein was detected on the blots by probing with a 1:5000 dilution of a rabbit polyclonal antibody raised against purified OmpR-His 6 (Brzostek et al., 2007). Then, secondary alkaline phosphataseconjugated goat anti-rabbit antibody was applied (1:1000) (Roche). Immunocomplexes were visualized using the chromogenic substrate nitroblue tetrazolium/5-bromo-4-chloro-3indolylphosphate (NBT/BCIP; Roche).

\section{CONSTRUCTION OF A rOvA::IacZYA CHROMOSOMAL TRANSCRIPTIONAL FUSION}

To obtain a chromosomal rovA::lacZYA transcriptional fusion, a 412-bp fragment of DNA encompassing a $3^{\prime}$ - end of the $\operatorname{rovA}$ gene, was amplified by PCR using the oligonucleotides rovA1X (5'-TGTCTAGATGATTTAGCACGATTAGTTCG-3') and rovA432S (5'-TGCCCGGGTTACTTACTTTGTAGTTGA ATAATG-3'), and the product was cloned into the cloning vector $\mathrm{pDrive}$ (Qiagen). The XbaI/SmaI rovA fragment was then subcloned into XbaI/SmaI digested pFUSE, a suicide vector that carries the promoterless lacZYA operon (Baumler et al., 1996). The resulting construct pFR1 was propagated in E. coli strain S17-1 $\lambda$ pir and transferred to $Y$. enterocolitica strains Ye9N and AR4 by biparental conjugation. Transconjugants YeR2 and ARR8 were selected on LB plates supplemented with $\mathrm{Nal}$ and $\mathrm{Cm}$ in the case of recipient strain Ye9N, or $\mathrm{Nal}, \mathrm{Cm}$ and $\mathrm{Km}$ for AR4. The recombination of the plasmid into the chromosome yielded strains, which carry a complete wild-type copy of the rovA gene. Correct integration at the rovA locus was confirmed by PCR and DNA sequencing (data not shown). PCRs were carried out using primers rovA01 (5'-TGAGAGCTCGACTTTGCCATCACGAGTCC-3') and placZ (5'-AGTCTCAATCTGCACTACAA-3'), which amplify a region starting before the $\operatorname{rov} A$ gene and including part of the lac $Z$ sequence present in pFUSE.

The functionality of the rovA promoter driving lacZYA expression in the selected transconjugant strains was confirmed by the production of a blue color following growth at $25^{\circ} \mathrm{C}$ on $\mathrm{LB}$ agar plates supplemented with 5 -bromo-4-chloro-3-indolyl- $\beta$-Dgalactopyranoside $\left(20 \mu \mathrm{g} \mathrm{ml}^{-1}\right)$.

The $\beta$-galactosidase activity of strains YeR2 and ARR8 grown under different temperature and $\mathrm{pH}$ conditions was measured by monitoring the degradation of $o$-nitrophenyl- $\beta$-D-galactoside into $o$-nitrophenol, which absorbs at $420 \mathrm{~nm}$.

OVERPRODUCTION AND PURIFICATION OF OmpR-HIS AND RovA-HIS $_{\mathbf{6}}$ The $\operatorname{ompR}$ structural gene was cloned in the expression vector pQE30 and an N-terminal His-tagged OmpR hybrid protein (OmpR-His ${ }_{6}$ ) was synthesized in E. coli M-15 and purified as described previously (Brzostek et al., 2007). Plasmid pETR1 carrying the entire rovA coding sequence under the control of the T7 promoter (see above) was used to transform E. coli BL21 (DE3). Expression and purification of the C-terminal His-tagged RovA hybrid protein ( RovA-His $_{6}$ ) was performed with Ni-NTA resin (Qiagen) according to the manufacturer's standard protocol. Briefly, E. coli BL21 (DE3) carrying plasmid pETR1 was grown to mid-logarithmic phase and induced with IPTG $(1 \mathrm{mM})$ for $4 \mathrm{~h}$ at $30^{\circ} \mathrm{C}$. The cells were then pelleted by centrifugation, resuspended in $50 \mathrm{mM}$ phosphate buffer ( $\mathrm{pH} 8.0$ ) containing $300 \mathrm{mM} \mathrm{NaCl}$, $55 \mu \mathrm{M}$ PMSF, $5 \mathrm{mM}$ imidazole and $10 \mathrm{mM}$ 2-mercaptoethanol, and disrupted by sonication. The sample was centrifuged and the supernatant passed through a Ni-NTA agarose column. The RovA-His 6 protein was eluted from the column in $50 \mathrm{mM}$ phosphate buffer $(\mathrm{pH} 8.0)$ containing $300 \mathrm{mM} \mathrm{NaCl}$ and $125 \mathrm{mM}$ imidazole, and then dialyzed at $4^{\circ} \mathrm{C}$ in $10 \mathrm{mM}$ Tris- $\mathrm{HCl}(\mathrm{pH} 7.5)$ buffer containing $5 \mathrm{mM}$ 2-mercaptoethanol, $10 \mathrm{mM} \mathrm{NaCl}$ and $5 \%$ glycerol. Aliquots of purified RovA-His 6 and OmpR-His 6 
hybrid proteins were stored at $-70^{\circ} \mathrm{C}$. Protein concentrations were determined using a Pierce BCA Protein assay kit with bovine serum albumin as the standard.

\section{ELECTROPHORETIC MOBILITY SHIFT ASSAYS (EMSAs)}

A 553-bp fragment of the inv promotor region $(-328$ to $+225 \mathrm{bp})$ encompassing the OmpR and RovA binding sites was obtained by PCR with primers GSinvF (5'-ATGACATCGCCATCACACTG-3') and GSinvR ( $5^{\prime}$-TTTTGCTGTGAGAACCCATAA-3'). The purified fragment $(\sim 20 \mathrm{ng}$ in $15 \mu \mathrm{l})$ was incubated for $30 \mathrm{~min}$ at room temperature with RovA-His 6 or OmpR-His 6 in the presence of the binding buffer $(40 \mathrm{mM}$ Tris- $\mathrm{HCl} \mathrm{pH} 8.0,100 \mathrm{mM}$ $\mathrm{KCl}, 10 \mathrm{mM} \mathrm{MgCl}_{2}, 5 \%$ glycerol) and the reactions were analyzed by electrophoresis in 6\% native polyacrylamide gels (29:1 acrylamide/bis acrylamide) in $0.5 \times$ TBE buffer. In some binding reactions the OmpR-His 6 used was phosphorylated by $30 \mathrm{~min}$ treatment with $20 \mathrm{mM}$ acetyl phosphate (Sigma). The DNA bands were visualized by silver staining using reagents in a kit, according to the manufacturer's protocol (Kucharczyk) or with ethidium bromide. Competitive EMSAs were performed by incubating the DNA first with RovA-His 6 protein followed by the addition of increasing amounts of OmpR-P-His 6 , or the inverse, where RovA$\mathrm{His}_{6}$ was added to reactions in which the DNA had first been incubated with OmpR-P-His ${ }_{6}$. As negative controls to confirm binding specificity, a 307-bp fragment of $16 \mathrm{~S}$ rDNA of $Y$. enterocolitica Ye9 or a 354-bp fragment of the ngoA302V gene from Neisserria gonorrhoeae FA1090 were included in the binding reactions. The PCR fragment of $16 \mathrm{~S}$ rDNA was generated by using primer 16SR1 5'-ATTCCGATTAACGCTTGCAC-3' and 16SR304 5'GTGGGGTAATGGCTCACCTA-3', the PCR ngoA302V fragment by primer VsrA1 5' -ACGCGTCGACCATGGATAAATTAACC-3' and VsrA354 5'-GCCAACACAAGAGCGGGTTTCGTCC-3'.

\section{SAMPLE PREPARATION AND PROTEIN IDENTIFICATION BY THE LIOUID CHROMATOGRAPHY-COUPLED TANDEM MASS SPECTROMETRY (LC-MS/MS)}

For the LC-MS/MS analysis, the DNA-protein complexes from the EMSA examining the competition between RovA (which was added first) and OmpR were separated in 6\% native polyacrylamide gel and stained with ethidium bromide. The slice of gel containing the shifted band from EMSA was excised with a clean scalpel. Prior to the LC-MS/MS analysis excised gel slice was subjected to the standard procedure of in-gel trypsin digestion, during which proteins were reduced with $100 \mathrm{mM}$ DTT for $30 \mathrm{~min}$ at $56^{\circ} \mathrm{C}$, alkylated with iodoacetamide in darkness for $45 \mathrm{~min}$ at room temperature, and digested overnight with $10 \mathrm{ng} / \mathrm{ml}$ trypsin. Peptides were eluted from gel with the water solution of $0.1 \%$ formic acid and $2 \%$ acetonitrile. Separation of peptides with high pressure liquid chromatography (nano-HPLC RP-18 column, $75 \mu \mathrm{M}$ id, Waters, Milford MA) and subsequent tandem mass spectrometry analysis (ESI-LTQ-FTICR, Thermo Electron Corp., San Jose, CA) was performed at the Mass Spectrometry Laboratory of Institute of Biochemistry and Biophysics, Polish Academy of Sciences, Warsaw, Poland. After preprocessing of the raw data with Mascot Distiller software (version 2.2.1, Matrix Science, London, UK), obtained peak lists were used to search the non-redundant protein database of the National Center for Biotechnology Information (NCBI) (10391716 sequences; 3545023166 residues) using the MASCOT search engine (version 2.2.03, 8-processors on-site license) (Matrix Science, London, UK).

\section{RESULTS}

\section{EFFECT OF TEMPERATURE AND pH CONDITIONS ON inv TRANSCRIPTION IN Ye9 STRAIN}

Early observations indicated that at neutral $\mathrm{pH}$ the expression of inv in Y. enterocolitica 8081 strain (serotype O8) is activated at $26^{\circ} \mathrm{C}$ and strongly repressed at $37^{\circ} \mathrm{C}$. In contrast, cells grown at $37^{\circ} \mathrm{C}$ at pH 5.5 exhibit the level of inv expression comparable to those at $26^{\circ} \mathrm{C}$ (Pepe et al., 1994). This low pH-dependent up-regulation of inv expression at $37^{\circ} \mathrm{C}$ has not been described for Y. pseudotuberculosis (Nagel et al., 2001). Recently, high and constitutive expression of inv at neutral $\mathrm{pH}$ has been described for $Y$. enterocolitica serotype $\mathrm{O} 3$ strains grown at $25^{\circ} \mathrm{C}$ and $37^{\circ} \mathrm{C}$ (Uliczka et al., 2011). To investigate whether the $\mathrm{pH}$-dependent regulation of inv occurs in Ye9 strain, RT-PCR analyses were carried out to study inv transcription. Figure 1 shows that the level of inv mRNA in cells grown at $37^{\circ} \mathrm{C}$ and $\mathrm{pH} 7.0$ was dramatically reduced, i.e., the inv transcript was not or barely visible. Furthermore, inv transcription was elevated at both temperatures when the $\mathrm{pH}$ was 5.5 . These data suggest that in $Y$. enterocolitica Ye9 strain (O9 serotype), the molecular control of inv

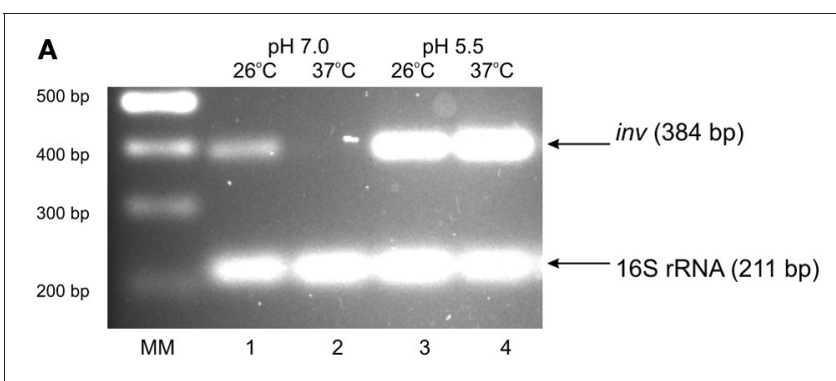

B

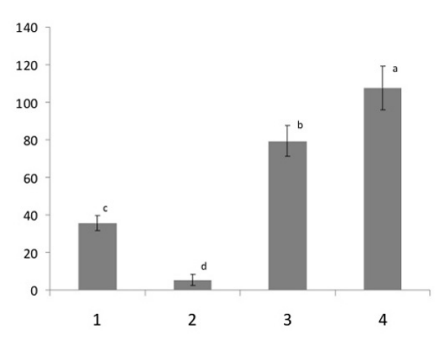

FIGURE 1 | Effect of $\mathrm{pH}$ and temperature on inv transcription in the wild-type strain Ye9. Cells were grown to stationary phase at $25^{\circ} \mathrm{C}$ or $37^{\circ} \mathrm{C}$ in LB medium buffered to $\mathrm{pH} 7.0$ or 5.5. Total RNA was extracted and used in sqRT-PCR to assess inv mRNA levels. PCRs for inv and 16S rRNA were carried out for 23 cycles and 10 cycles, respectively. (A) Lanes: MM-DNA molecular mass marker (100 bp ladder); lane $1-25^{\circ} \mathrm{C}, \mathrm{pH} 7.0$; lane $2-37^{\circ} \mathrm{C}, \mathrm{pH} 7.0$; lane $3-25^{\circ} \mathrm{C}, \mathrm{pH} 5.5$; lane $4-37^{\circ} \mathrm{C}, \mathrm{pH}$ 5.5. (B) The densities of inv bands relative to those of the 16S rRNA bands on the gel in part A. Values are means $\pm S D, n=2-3 ; a, b, c, d$-results of Tukey post-hoc multiple mean comparison test. Means without a common letter differ significantly $(p<0.05)$ 
transcription in response to changes in $\mathrm{pH}$ differs from that described for other Y. enterocolitica serotypes/strains.

\section{THE EXPRESSION PATTERN OF OmpR IN RESPONSE TO DIFFERENT TEMPERATURE AND $\mathrm{pH}$ CONDITIONS}

The regulation of virulence genes by environmental cues is achieved by alterations in the level or activity of regulatory proteins. It has been shown previously that phosphorylation of OmpR activates this regulatory protein (McCleary and Stock, 1994; Lan and Igo, 1998). Just as the activation/phosphorylation of OmpR might influence inv transcription, so too might the expression of $o m p R$. To study whether $o m p R$ expression responds to changes in temperature and $\mathrm{pH}$, the levels of the $\operatorname{ompR} \mathrm{R}$ transcript in wild-type Ye9 cells were analyzed by sqRT-PCR. We examined $o m p R$ transcript abundance in strain Ye9 grown to early stationary phase at $25^{\circ} \mathrm{C}$ and $37^{\circ} \mathrm{C}$ in buffered $\mathrm{LB}$ medium at $\mathrm{pH}$ 7.0 or 5.5 (Figure 2). The ompR mRNA level at neutral pH 7.0 was markedly lower at $37^{\circ} \mathrm{C}$ compared with $25^{\circ} \mathrm{C}$, which indicated that $\operatorname{omp} R$ transcription is temperature-dependent. Moreover, we found an increase in the level of the ompR transcript at pH 5.5 at both temperatures, although the degree of response to low $\mathrm{pH}$ was slightly higher at $37^{\circ} \mathrm{C}$ than at $25^{\circ} \mathrm{C}$. To determine whether the differences in the transcription of $\operatorname{ompR}$ in strain Ye9 were reflected in the level of OmpR protein, Western blot analysis was performed using a polyclonal antibody raised against purified OmpR (Figure 3). Immunoblotting of cytoplasmic proteins of strain Ye9 grown at $\mathrm{pH} 7.0$ showed no trace of OmpR protein at $37^{\circ} \mathrm{C}$, whereas in the extract from cells at $25^{\circ} \mathrm{C}$, a clear immunoreactive band was detected. In cells propagated at $\mathrm{pH}$ 5.5, increased OmpR protein levels were observed at both temperatures. These data revealed that levels of OmpR protein essentially correlate with the amount of ompR transcript in cells grown at different temperatures $\left(25\right.$ and $\left.37^{\circ} \mathrm{C}\right)$ and $\mathrm{pH}(\mathrm{pH} 7.0$ and 5.5).

\section{EFFECT OF GROWTH CONDITIONS AND OmpR ACTIVITY ON rOVA PROMOTER FUNCTION}

Our previous in vitro studies showed that OmpR from strain Ye9 is able to bind specifically to the inv promoter region leading to the repression of $i n v$ transcription. As well as having a possible direct effect on inv expression, OmpR may also influence rovA expression. To determine whether the loss of OmpR

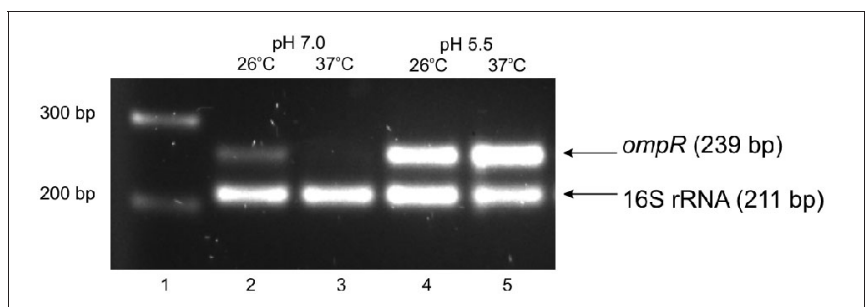

FIGURE 2 | Effect of $\mathrm{pH}$ and temperature on ompR transcription in the wild-type strain Ye9. Cells were grown to early stationary phase at $25^{\circ} \mathrm{C}$ or $37^{\circ} \mathrm{C}$ in LB medium buffered to $\mathrm{pH} 7.0$ or 5.5. Total RNA was extracted and used in sqRT-PCR to assess ompR mRNA levels. PCRs for ompR and 16S rRNA were carried out for 25 cycles and 10 cycles, respectively. Lanes: 1 -DNA molecular mass marker (100 bp ladder); lane $2-25^{\circ} \mathrm{C}$, $\mathrm{pH} 7.0$; lane $3-37^{\circ} \mathrm{C}, \mathrm{pH} 7.0$; lane $4-25^{\circ} \mathrm{C}, \mathrm{pH} 5.5$; lane $5-37^{\circ} \mathrm{C}, \mathrm{pH} 5.5$.

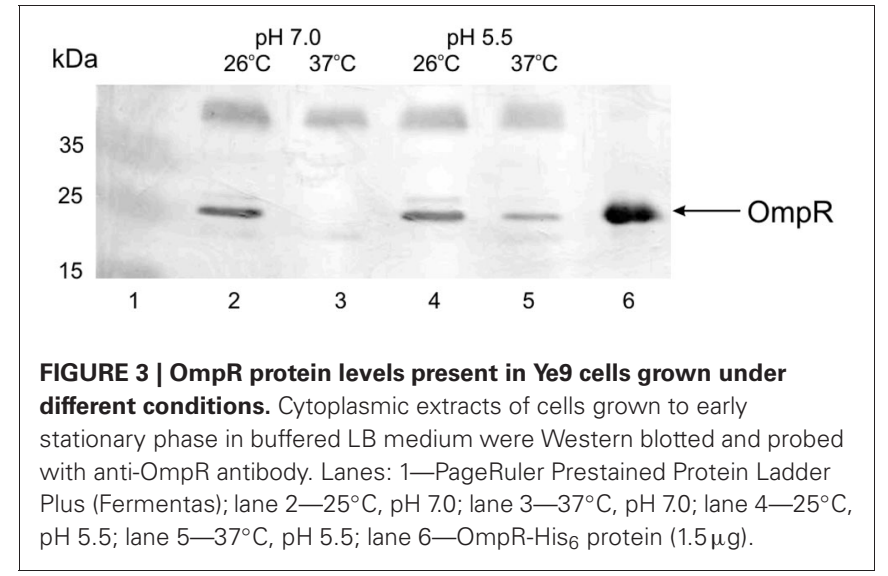

alters rovA expression, a rovA::lacZYA chromosomal transcriptional fusion was created in $Y$. enterocolitica strain Ye9N and AR4 (ompR mutant) via homologous recombination, yielding strains YeR2 $\left(\mathrm{OmpR}^{+}\right)$and ARR8 $\left(\mathrm{OmpR}^{-}\right)$, respectively. The $\beta$-galactosidase activity was then measured in both strains grown under different $\mathrm{pH}$ and temperature conditions (Figures 4A,B). We found that $\mathrm{pH}$ significantly influences the $\beta$-galactosidase activity at different temperatures (ANOVA: for YeR2, $25^{\circ} \mathrm{C}$ $F_{(6.14)}=34.510, p<0.001$; for $\mathrm{YeR} 2,37^{\circ} \mathrm{C} F_{(6.14)}=14.008$, $p<0.001$; for ARR8, $25^{\circ} \mathrm{C} F_{(6.14)}=130.551, p<0.001$; for ARR8, $\left.37^{\circ} \mathrm{C} F_{(6.14)}=12.673, p<0.001\right)$.

The optimal $\mathrm{pH}$ for rovA expression in YeR2 $\left(\mathrm{OmpR}^{+}\right)$and ARR8 $\left(\mathrm{OmpR}^{-}\right)$was found to be 7.5 at both temperatures and raising the $\mathrm{pH}$ to 8.5 did not lead to changed rovA promoter activity. However, we observed that the activity of rovA promoter, measured by assaying for $\beta$-galactosidase activity, was about 2fold lower in YeR2 and ARR8 cells grown at $\mathrm{pH} 7.5$ at $37^{\circ} \mathrm{C}$ compared with $25^{\circ} \mathrm{C}(p<0.001)$. Moreover, a shift to acidic $\mathrm{pH}$ values at $25^{\circ} \mathrm{C}$ resulted in a significant fall in rovA activity with the greatest decrease of $\sim 6$-fold occurring when the $\mathrm{pH}$ was reduced to $5.0(p<0.001)$. Analysis of rovA expression in YeR2 and ARR8 cells grown at $37^{\circ} \mathrm{C}$ under different $\mathrm{pH}$ conditions (at $\mathrm{pH}$ values below 7.5) demonstrated also a significant reduction in rovA promoter activity. However, a shift from pH 7.5 to 5.0 resulted only in a $\sim 2$-fold decrease for YeR2 cells.

In summary, our data demonstrated temperature-dependent expression of rov $A$, namely reduced rovA expression at $37^{\circ} \mathrm{C}$ compared with that at $26^{\circ} \mathrm{C}$, confirming the results previously obtained for Y. enterocolitica serotype O8 and Y. pseudotuberculosis (Heroven et al., 2004; Ellison and Miller, 2006b). In addition, no significant differences $(p>0.05)$ in the activity of rovA measured under different $\mathrm{pH}$ and temperature conditions were observed in cells with and without OmpR, indicating that OmpR does not influence rovA expression.

In contrast, at $\mathrm{pH} 5.0$ at $37^{\circ} \mathrm{C}$ significant differences $(p<0.05)$ in the activity of rovA promoter were observed in cells with and without OmpR, indicating that OmpR might influence rovA expression under these particular conditions.

\section{OmpR-AND RovA-DEPENDENT inv REGULATION IN $Y$. enterocolitica}

The expression of inv in Y. enterocolitica is known to be positively regulated by RovA protein acting mainly as an anti-repressor of 


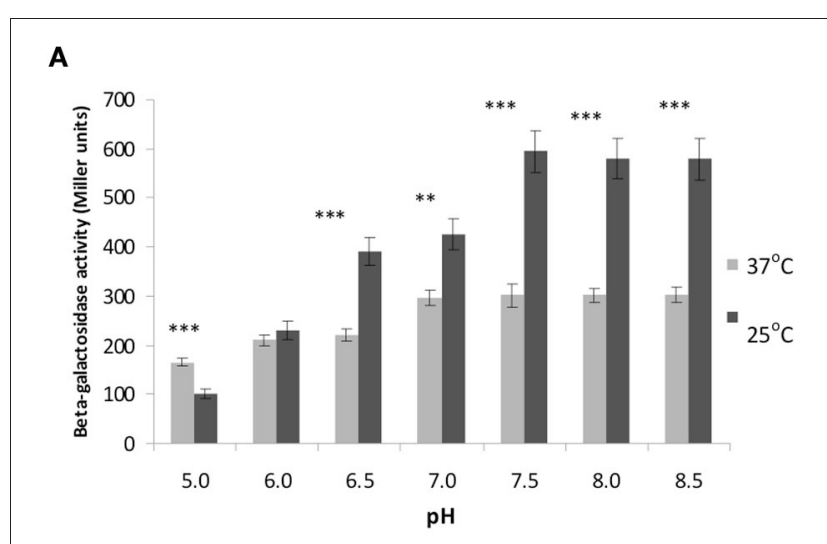

B

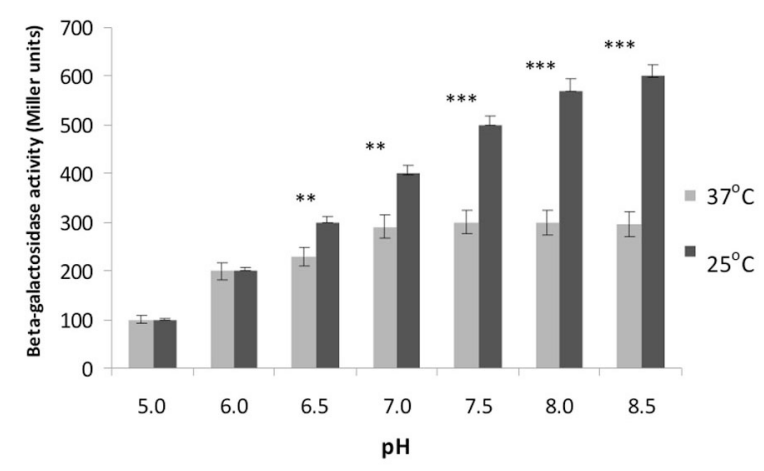

FIGURE 4 | Effect of OmpR and different temperature and $\mathrm{pH}$ conditions on rov $A$ expression determined using a rovA::IacZYA operon fusion. $\beta$-galactosidase activities were measured in strain YeR2 $\left(\mathrm{OmpR}^{+}\right)$and in the isogenic mutant strain ARR8 $\left(\mathrm{OmpR}^{-}\right)$grown to early stationary phase in $\mathrm{LB}$ medium at different $\mathrm{pH}$ at $25^{\circ} \mathrm{C}$ (A) or $37^{\circ} \mathrm{C}$ (B). The data presented are the means of three-independent experiments \pm SD. Statistical significance was calculated using Student's $t$-test. ${ }^{* *} p<0.01$; $* * * p<0.001$

the H-NS/YmoA complex. To determine whether the inhibitory effect of OmpR correlates with RovA activity, a rovA null mutation was introduced into strains Ye9 and AR4 (ompR mutant) by insertional mutagenesis using the plasmid pEP185.2. The engineered Y. enterocolitica (rovA::pEP185.2) mutants were named AS3 and AC1, respectively. To perform complementation analyses, plasmid pETRlac (carrying the cloned rovA gene) was introduced in trans to the strain AS3. The effect of overproduction of RovA in Y. enterocolitica cells was monitored in wild-type strain Ye9 carrying plasmid pETRlac. The level of inv transcription was examined in cells grown in LB medium at neutral $\mathrm{pH}$ and moderate temperature - conditions known to produce high level inv expression. SqRT-PCR was used to measure changes in the mRNA level in $\operatorname{rov} A, o m p R$, and rovA ompR mutants (Figure 5). As anticipated, higher levels (increase by 35\%) of inv mRNA were observed in the ompR mutant AR4 compared with the wildtype strain Ye9 indicating the negative role played by OmpR. (Figure 5, lane 5 vs. 1). In contrast, the level of the inv transcript was reduced 2-fold in the rovA mutant background of strain AS3 (Figure 5, lane 2 vs. 1). The positive effect of RovA on inv transcription was confirmed by complementation analysis where the plasmid pETRlac was introduced in trans to the rovA mutant. RovA protein produced by pETRlac restored the activity of the inv promoter almost to the wild-type level (Figure 5, lane 3 vs. 2). The increased level of RovA expressed from pETRlac also led to much (nearly 2-fold) higher inv expression in wild-type cells (Figure 5, lane 4 vs. 1). Moreover, when the inv transcription was relieved from the negative effect of the OmpR protein in the rovA mutant background of strain $\mathrm{AC1}(\mathrm{ompR}$, rovA), the level of inv mRNA decreased over 2-fold compared with that observed in ompR mutant AR4 with active RovA (Figure 5, lane 6 vs. 5). These data indicated that removal of OmpR leads to higher inv expression level only in the presence of RovA. Conversely, when RovA is absent, the inhibition of inv transcription can be seen regardless of the presence of OmpR and probably results from the activity of the H-NS/YmoA repression complex.

\section{INTERACTION OF OmpR AND RovA WITH THE inv PROMOTER REGION in vitro}

A detailed characterization of RovA in $Y$. enterocolitica and $Y$. pseudotuberculosis showed that this regulator positively regulates inv expression by acting mainly as a derepressor that competes with $\mathrm{H}-\mathrm{NS}$ for binding sites within the inv promoter (Heroven et al., 2004; Ellison and Miller, 2006b). Two RovA binding sites, previously recognized in $Y$. enterocolitica $\mathrm{O} 8 \mathrm{inv}$ promoter, are located between -177 and $-38 \mathrm{bp}$ relative to the transcriptional start site and overlap with two H-NS binding sites (Figure 6). In addition, the examination of inv promoter sequence indicated that RovA binding sites and the putative OmpR binding site (between -15 and $-33 \mathrm{bp}$ ), predicted by in silico analysis and confirmed by in vitro band-shift assays (Brzostek et al., 2007), do not overlap. Thus, these regulators may bind independently to the inv promoter, although the binding of one of these proteins to DNA may influence the interaction of the other. To gain further insight into the interactions of OmpR and RovA with the inv promoter, electrophoretic mobility shift assays (EMSAs) were performed.

To determine whether both RovA and OmpR bind specifically to the inv promoter region, a PCR-amplified 553-bp fragment comprising the binding sites of both these proteins was used in band-shift assays. Recombinant OmpR-His 6 and RovA-His 6 proteins were expressed in E. coli and purified to homogeneity by affinity chromatography using Ni-NTA agarose. The purity of the RovA $(18 \mathrm{kDa})$ and OmpR $(27 \mathrm{kDa})$ hybrid proteins was verified by electrophoresis on $12 \%$ SDS-polyacrylamide gels (data not shown). Different amounts of the purified proteins were incubated with the inv promoter fragment and these binding reactions were analyzed by electrophoresis in $6 \%$ native polyacrylamide gels. The results presented in Figure 7 demonstrate that RovA from Y. enterocolitica Ye9 binds to the inv promoter fragment to form DNA-protein complexes. An apparent stepwise shifting of the inv fragment with increasing amounts of RovA $(0.125-1.0 \mu \mathrm{g})$ was observed, suggesting the presence of more than one RovA binding site in the inv promoter region. The interaction of RovA with the inv promoter appears to be specific, since at the concentration required for binding of the inv promoter fragment, this protein did not bind the 300-bp control fragment derived 


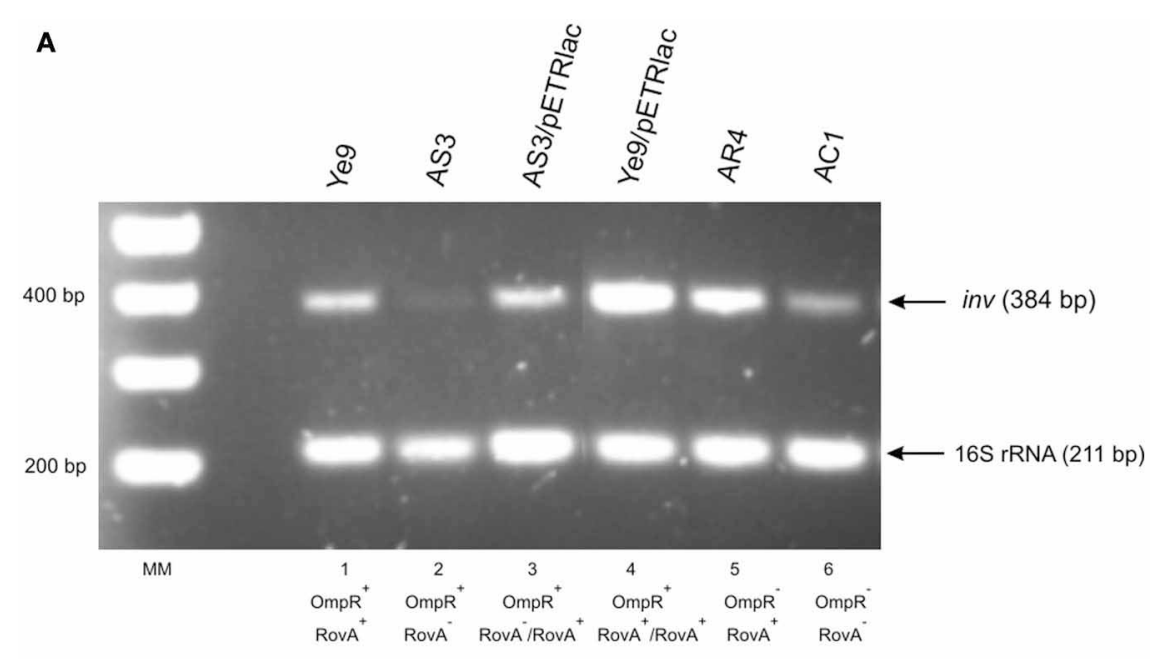

B

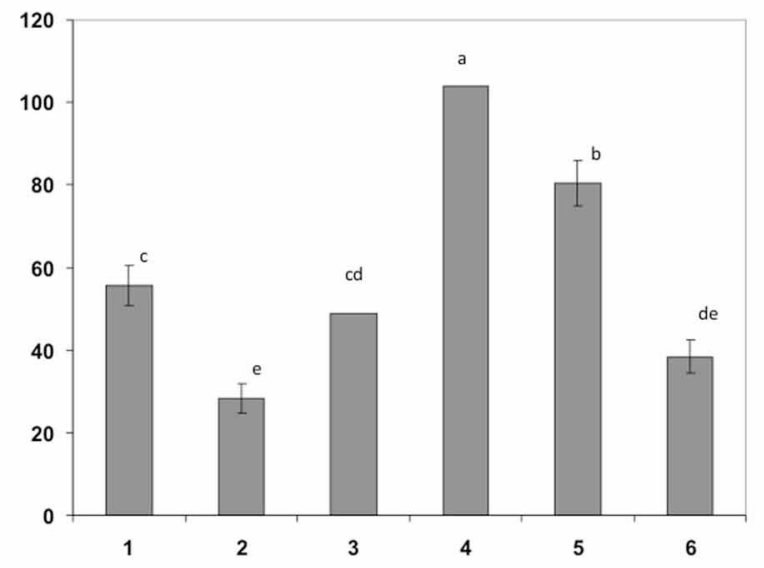

FIGURE 5 | Influence of OmpR and RovA proteins on inv transcription in wild-type $Y$. enterocolitica, $\operatorname{rov} A, \operatorname{ompR}$ and $\operatorname{rovAompR}$ mutants, and complemented strains. Cells were grown to early stationary phase at $25^{\circ} \mathrm{C}$ in LB medium ( $\mathrm{pH}$ 7.0). Total RNA was extracted and used in sqRT-PCR to assess inv mRNA levels. PCRs for inv and 16S rRNA were carried out for 28 cycles and 16 cycles, respectively. The PCR reactions were mixed before loading onto the gel. (A) Lanes: MM-DNA molecular mass marker
(100 bp ladder); 1-Ye9 (WT); 2-AS3 (rovA mutant); 3-AS3/pETRlac; 4-Ye9/pETRlac; 5-AR4 (ompR mutant); 6-AC1 (ompRrovA mutant). (B) The densities of inv bands relative to those of the 16S rRNA bands on the gel in part A. RT-PCR signals were averaged from 3 replicates (lanes 1, 2, 5, 6). Values are means $\pm S D ; a, b, c, d$, e-results of Tukey post-hoc multiple mean comparison test. Means without a common letter differ significantly $(p<0.05)$ from the $n g o A 302 \mathrm{~V}$ gene of Neisserria gonorrhoeae FA1090. The EMSA using OmpR demonstrated that the interaction of this protein with the inv promoter fragment produced one visible nucleoprotein band irrespective of the amount of OmpR added to the binding reaction $(0.1-0.4 \mu \mathrm{g})$ (Figure 8). Furthermore, differences in the mobility of the shifted DNA-protein complex were observed when non-phosphorylated and phosphorylated (by acetyl-P) forms of OmpR were used (Figure 8, lanes 2-5 vs. 6-9). In addition, the minimum amount of phosphorylated OmpR that was able to bind the inv promoter fragment was approximately 3 -fold lower than that for the non-phosphorylated OmpR. No mobility shift of the $16 \mathrm{~S}$ rDNA control fragment was detected under any of the conditions tested.

EMSAs to examine competition between RovA and OmpR for binding to the inv regulatory region tested the effect of the order of binding, i.e., RovA added to the DNA before OmpR and vice versa (Figure 9). Initially, the 553-bp inv promoter fragment was first incubated with $\mathrm{OmpR}$ and then increasing amounts of RovA were added to the binding reaction (Figure 9, lanes 2-5). The OmpR protein, once bound to DNA, was not modified or displaced by RovA, since specific RovA-DNA complexes were not observed. In the inverse reactions, incubation of the inv promoter fragment first with RovA followed by the addition of increasing amounts of OmpR resulted in the disappearance of RovA-DNA complexes. In addition, a slower migrating band appeared at a lower concentration of OmpR (Figure 9, lane 7). To determine whether RovA is part of this slow mobility complex, the slice of gel containing the shifted band from EMSA, visualized by ethidium bromide staining, was subjected to LC-MS/MS analysis (Figure 10). Mass spectrometry identified two types of proteins: 
4321 agccagcggttgcttagccgcattagattaatgcatcgtgaaaatgcagagagtctatt

4381 ttatgagacgaatgtaagctattttgataataataacatatcaccatatatattcaggct

משח

4441 aaatataacctgacaattaaattagcaagctaatattaccatgatgaattttttttgca $\square$

$-35$

$-10$

4501 tttcatttgttattgctgttattttaatttttaattttatttttgtaagttctgctat

$+1$

4561 tatattgtattgttagtgtttgcgagagagaagaagaagttatttcttgtcgetgtttc

4621 atttctgttgcttagtaatattaccgcgttaatttatacctaaggggtacacta ATG

SD

M

4681 TAT TCA TTT

Y S F

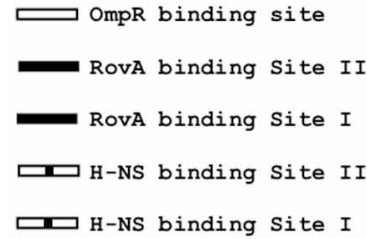

FIGURE 6 | OmpR, RovA and H-NS binding sites in the promoter region of inv in $\boldsymbol{Y}$. enterocolitica. Two RovA and $\mathrm{H}-\mathrm{NS}$ binding sites (I and II), (Ellison and Miller, 2006b) and the putative OmpR binding site

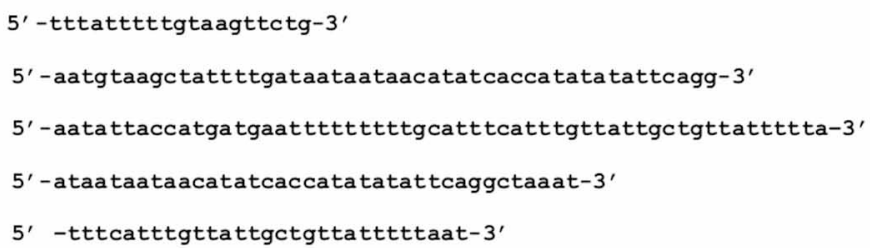

(Brzostek et al., 2007) are underlined. The transcriptional start site of the inv promoter (+1), ATG start codon and Shine-Dalgarno (SD) sequences are indicated.
OmpR, classified according to the protein database of NCBI as the osmolarity response regulator of $Y$. enterocolitica and RovA, classified as the transcriptional regulator SlyA (RovA is a member of Mar/SlyA family). Thus, using this approach we were able to demonstrate the co-migration of OmpR and RovA to the same region of the gel during in vitro EMSA. However, these results do not necessarily imply simultaneous binding of these two proteins. The presented results are an initial attempt to gain some insight into the mechanism of RovA/OmpR interplay and additional experiments need to be performed to confirm this hypothesis.

\section{DISCUSSION}

In enteropathogenic Yersinia, signals from the environment seem to play a crucial role in the control of inv synthesis by engaging a number of activator and repressor proteins which together form a complex regulatory system (Ellison et al., 2004; Ellison and Miller, 2006b; Carlsson et al., 2007). Most investigations of $Y$. enterocolitica inv have been performed using highpathogenicity $Y$. enterocolitica strain $8081 \mathrm{v}$ of bioserotype 1B/O8. Recent intensive genetic and physiological studies have revealed significant differences in the pattern of inv synthesis between different serotypes and strains (high- and low-pathogenicity bioserotypes) in response to conditions including temperature and growth phase. While the expression of inv in Y. enterocolitica serotype $\mathrm{O} 8$ was high at moderate temperature, dramatically reduced at $37^{\circ} \mathrm{C}$, and up-regulated at $37^{\circ} \mathrm{C}$ under low $\mathrm{pH}$ conditions, its expression in serotype $\mathrm{O} 3$ strains was found to be constitutive and significantly enhanced due to an IS insertion that provides specific activating elements (Uliczka et al., 2011). Analysis of the inv promoter activity using the luxCDABE reporter system revealed differences in inv expression between strains of serotypes O8 and O9 (Trček et al., 2010). However, neither specific regulatory factors nor the structure of the respective inv promoter regions seem to be responsible for the observed differences. Furthermore, in light of the data from these studies, it is possible that specific regulation of inv expression occurs at the single cell level.

Our previous study performed with $Y$. enterocolitica strain Ye9 (serotype O9) showed a significant decrease in inv expression at $37^{\circ} \mathrm{C}$ at neutral $\mathrm{pH}$, similar to that seen in $Y$. enterocolitica serotype $\mathrm{O} 8$ (Brzostek et al., 2007). In the present study, low $\mathrm{pH}$-dependent inv gene induction was demonstrated at both $25^{\circ} \mathrm{C}$ and $37^{\circ} \mathrm{C}$ in strain Ye9, which is different from the pattern of inv transcription observed previously in serotype 


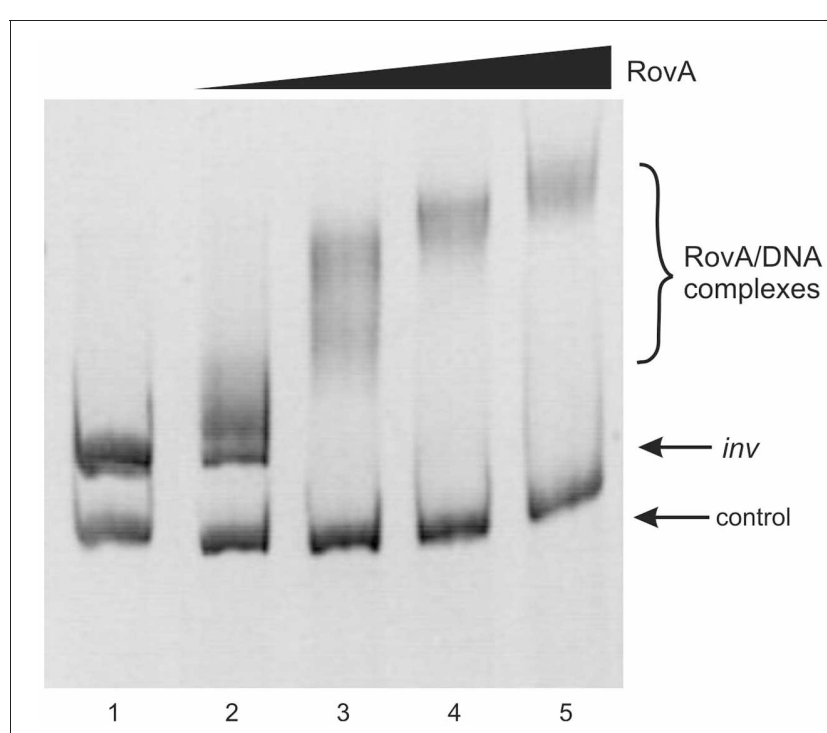

FIGURE 7 | Interaction of purified RovA from Ye9 strain with the inv promoter region examined in EMSA. EMSA showing the binding of increasing quantities of RovA-His 6 to the inv promoter region, using a 553-bp inv DNA fragment $(-328$ to +225$)$ encompassing the RovA binding sites. The amount of RovA added was $0,0.125,0.25,0.5$, and $1.0 \mu \mathrm{g}$ (lanes 1-5). A 300-bp fragment of the ngoA302 V gene from Neisserria gonorrhoeae FA1090 was used as a negative control. DNA-protein complexes were separated by electrophoresis in $6 \%$ native polyacrylamide gels and silver stained.

O8 (Pepe et al., 1994). Therefore, genetic variation in separate bio-serotypes of $Y$. enterocolitica may lead to differences in inv expression.

The OmpR protein is a response regulator of the EnvZ/OmpR TCS that senses osmolarity and $\mathrm{pH}$ conditions (Aiba et al., 1989; Bang et al., 2000). In Y. enterocolitica Ye9, OmpR negatively affects inv transcription at moderate temperature and neutral $\mathrm{pH}$ (Brzostek et al., 2007). Studies on related EnvZ/OmpR signaling pathways in other enteric bacteria have shown that the modulation of gene expression is often mediated by OmpR regulatory proteins, which are themselves tightly regulated (Huang et al., 1992; Bang et al., 2000, 2002). Thus, besides the functional state of OmpR (i.e., the level of phosphorylation), changes in OmpR expression mediated by environmental signals could influence inv gene transcription. In the present study, the pattern of ompR transcription in Y. enterocolitica Ye9 exhibited marked differences in response to changes in temperature (reduced expression at $37^{\circ} \mathrm{C}$ vs. $25^{\circ} \mathrm{C}$ ). In addition, a marked increase in $o m p R$ transcription was observed at $\mathrm{pH} 5.5$ compared with $\mathrm{pH}$ 7.0, highlighting the acid-induced nature of $o m p R$ expression, as previously described in Y. pestis and Salmonella enterica (Hu et al., 2009a; Gao et al., 2011). These changes in expression, demonstrated at the mRNA level, were also observed at the protein level when cytoplasmic OmpR was evaluated by Western blotting. It is intriguing that inv transcription increases under conditions where the highest levels of $\operatorname{ompR}$ induction occur (at $\mathrm{pH}$ 5.5). Thus, we cannot rule out the possibility that under these environmental conditions, OmpR could positively modulate the expression of inv through interactions with other putative inv regulators implicated in

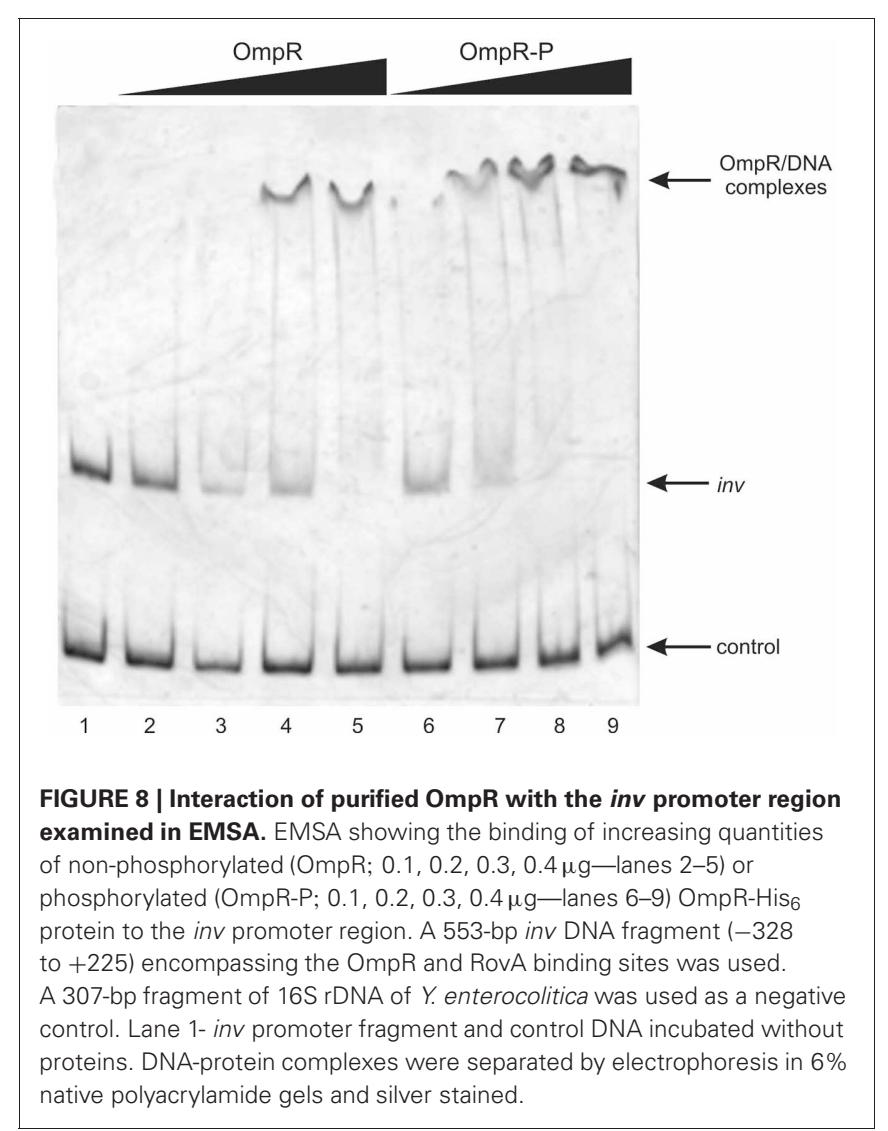

$\mathrm{pH}$-dependent regulation. This phenomenon is currently being investigated in greater detail.

To learn more about the involvement of $\mathrm{OmpR}$ in the inv regulatory circuit of Y. enterocolitica strain Ye9-in which RovA should play a major role-we evaluated the level of inv transcription in $\operatorname{omp} R, \operatorname{rov} A$, and $\operatorname{omp} R \operatorname{rovA}$ mutant backgrounds. As anticipated, in the presence of RovA, the lack of OmpR led to an increase in inv transcription. However, in the $\operatorname{rov} A$ mutant background, this effect was no longer visible. These data showed that the inhibitory effect of OmpR on inv expression can be observed when RovA is present/active in Y. enterocolitica cells and suggest that, RovA does not act as a derepressor of OmpR inv inhibition. However, this scenario is complicated by the fact that in the absence of RovA, another regulatory protein, namely $\mathrm{H}-\mathrm{NS}$, probably operates as the main repressor of inv expression and overcomes the repressive activities of OmpR under the tested growth conditions. H-NS has previously been shown to contribute to the inhibition of inv expression, either alone (Y. pseudotuberculosis) or together with YmoA (Y. enterocolitica) (Heroven et al., 2004; Ellison and Miller, 2006b). Thus, our results suggest that OmpR might influence inv expression by inhibiting RovA-dependent inv activation. It has previously been shown that RovA, besides its anti-H-NS repressor activity, might directly stimulate inv transcription. This type of RovA activity, leading to increased inv transcription, has been observed in Y. pseudotuberculosis (Tran et al., 2005). The lack of success in obtaining a Yersinia hns mutant led to the construction of a heterologous system in E. coli, which 


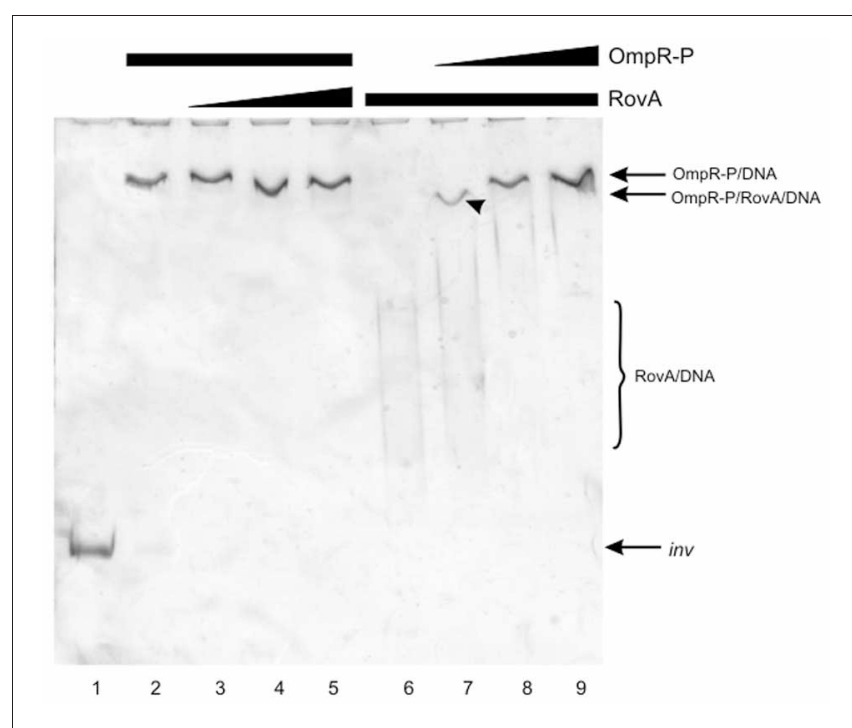

FIGURE 9 | Competition for binding the inv promoter fragment between OmpR and RovA proteins. EMSAs examining competition for binding the inv promoter fragment between OmpR-P, which was added first $(0.3 \mu \mathrm{g}$-lanes $2-5)$, and RovA $(0.05,0.125,0.25 \mu \mathrm{g}$, lanes 3-5 respectively); and between RovA, which was added first $(0.25 \mu \mathrm{g}$, lanes 6-9), and OmpR-P (0.05, 0.15, 0.3 $\mu \mathrm{g}$-lanes 7-9). A 553-bp inv DNA fragment $(-328$ to +225 ) encompassing the OmpR and RovA binding sites was used. Lane 1-inv promoter fragment incubated without proteins. DNA-protein complexes were separated by electrophoresis in $6 \%$ native polyacrylamide gels and silver stained. The arrowhead indicates the band excised for MS/MS analysis.

\section{A}

1 MOENHKILVV DDDMRLRALI ERYLTEQGFQ VRSVADAEQM DRLLTRESFH 51 LMVLDLMLPG EDGLSICRRI RSOSNPMPII MVTAKGEEVD RIVGLEIGAD 101 DYIPKPFNPR ELLARIRAVL RRQANELPGA PSQEEAVIAF GKFKLNLGTR 151 EMSREDEPMP LTSGEFAVLK ALVSHPREPL SRDKLINLAR GREYSAMERS 201 IDVQISRLRR MVEEDPAHPR YIQTVWGLGY VFVPDGSKA

B

1 MESTLGSDLA RLVRVWRALI DHRLKPLELT QTHWVTLHNI NRLPPEQSQI 51 QLAKAIGIEQ PSLVRTLDQL EEKGLITRHT CANDRRAKRI KLTEQSSPII 101 EQVDGVICST RKEILGGISP DEIELLSGLI DKLERNIIQL QSK

FIGURE 10 | Amino acid sequencing and bioinformatic analysis of proteins identified by the LC-MS/MS. The DNA-protein complexes (indicated by the arrowhead at Figure 9) were subject to the MS/MS analysis. MS/MS data were used to search protein database. (A) The amino acid sequences of OmpR Y. enterocolitica strain Ye9 (GI 28912448) and RovA Y. enterocolitica 8081 (GI 123442405) derived from the NCBI database (B). Peptides detected by MS/MS analysis are indicated in bold. Sixty-nine percentage of OmpR and forty-five percentage of RovA protein sequence are covered by matching peptides.

has been used to study the regulatory role of the H-NS protein (Heroven et al., 2004; Ellison and Miller, 2006b). Using this approach, we recently demonstrated a marked increase in inv expression in E. coli strains carrying a mutation in either the hns or $\operatorname{ompR}$ genes. Moreover, our studies using an E. coli hns strain indicated that the RovA protein of Y. enterocolitica O9 may act as an activator of inv expression, while OmpR seems to repress the RovA-dependent activation of the inv gene (Raczkowska et al., 2011a).

To study the nature of the interactions of RovA and OmpR with the inv promoter region in $Y$. enterocolitica $\mathrm{O} 9$ and to characterize the interplay between these regulatory proteins, we performed DNA mobility shift assays. When used separately in EMSAs, OmpR and RovA could bind specifically to an inv DNA fragment comprising the putative OmpR and RovA binding sites. These assays suggested that OmpR binds to a unique site within the inv promoter, confirming our previous findings and the results of in silico analysis (Brzostek et al., 2007). In contrast, the binding properties of RovA raised the possibility of the presence of more than one RovA binding site within the inv promoter. Two potential RovA binding sites (low and high affinity) were previously identified in the inv promoter of Y. enterocolitica and Y. pseudotuberculosis, and it has been suggested that optimal expression of inv depends on the interaction of RovA molecules with these sequences (Nagel et al., 2001; Heroven et al., 2004; Ellison and Miller, 2006b). In competitive DNA mobility shift assays, the addition of increasing concentrations of RovA to a constant amount of OmpR already bound to the inv promoter fragment, did not lead to changes in the mobility of the nucleoprotein complexes. However, in the opposite scenario, the disappearance of RovA-DNA complexes was observed upon the addition of increasing amounts of OmpR and this was accompanied by the appearance of a major protein-DNA complex of reduced mobility. Mass spectrometry analysis revealed the presence of both the RovA and OmpR proteins in this slower migrating complex. This co-migration may indicate the simultaneous binding of these proteins at the inv promoter (the OmpR and RovA recognition sites in the inv promoter do not overlap). Simultaneous binding of both regulators might reflect a potential mechanism of RovA/OmpR interplay influencing inv expression. However, our data are preliminary in nature and confirmation of this hypothesis awaits more detailed experiments including supershift assays with specific OmpR and RovA antibodies and DNA footprinting with DNA fragments lacking the predicted binding sites. Such studies may shed light on the mechanism of RovA/OmpR interplay and the possibility that activated OmpR might bind to its specific binding site even in the presence of RovA protein, or that binding of OmpR may disturb RovA binding (at the low affinity site located near the putative OmpR binding site). The presence of two RovA binding sites within the inv promoter, of high and low affinity, may permit fine-tuning of inv expression by RovA, OmpR and other regulatory proteins that interact with the inv regulatory sequence.

In addition, our EMSA data indicated that phosphorylation of OmpR by acetyl-phosphate may result in its activation, leading to slight enhancement of its binding abilities.

OmpR phosphorylation, by acetyl-phosphate and other phospho-donors or related kinases, has previously been suggested for E. coli, (Forst et al., 1990; McCleary and Stock, 1994; Shin and Park, 1995; Matsubara and Mizuno, 1999) and for Y. enterocolitica (Raczkowska et al., 2011b).

As a final experiment to characterize the regulation of inv gene expression, a rovA::lacZYA chromosomal fusion was used to examine whether the OmpR regulator could influence rovA 
transcription. Our results indicated that OmpR has no effect on $\operatorname{rovA}$ transcription, which suggests that the influence of OmpR on inv expression does not occur through modulation of RovA levels. These data also showed significant differences in the activity of the rovA promoter in Y. enterocolitica Ye9 cells grown at different temperatures. Expression of RovA in response to conditions including temperature and growth phase is important for the environmentally-controlled expression of inv in enteropathogenic Yersinia (Nagel et al., 2001; Heroven et al., 2004; Ellison and Miller, 2006b). We found lower levels of rovA expression at $37^{\circ} \mathrm{C}$ compared with $25^{\circ} \mathrm{C}$. However, our data showed only a 2 -fold decrease in the activity of the rovA promoter in $Y$. enterocolitica Ye9 cells grown at $37^{\circ} \mathrm{C}$ compared to $25^{\circ} \mathrm{C}$, which contrasts with similar data for Y. enterocolitica $\mathrm{O} 8$ and Y. pseudotuberculosis, showing that the levels of rovA transcription were reduced by 4-fold at the higher temperature (Nagel et al., 2001; Lawrenz and Miller, 2007). Thus, the precise mechanism of thermoregulation of inv governed by RovA protein might be different in high- and low-pathogenicity bioserotypes of Y. enterocolitica. The regulation of rovA in $Y$. pseudotuberculosis is mediated by the H-NS and RovA proteins, and probably follows the mechanism proposed for the inv gene. The available data suggest that, similarly to the regulation of inv gene expression, the relative levels of RovA and H-NS could be responsible for controlling rovA expression. However, the regulation of rovA in Y. enterocolitica may be less straightforward, with the latest findings indicating the possible indirect involvement of RovA in regulating rovA expression (Lawrenz and Miller, 2007). In addition, a third protein

\section{REFERENCES}

Aiba, H., Nakasai, F., Mizushima, S., and Mizuno, T. (1989). Evidence for the physiological importance of the phosphotransfer between the two regulatory components, EnvZ and OmpR, in osmoregulation in Escherichia coli. J. Biol. Chem. 264, 14090-14094.

Atlung, T., and Ingmer, H. (1997). HNS: a modulator of environmentally regulated gene expression. Mol. Microbiol. 24, 7-17.

Bang, I. S., Audia, J. P., Park, Y. K., and Foster, J. W. (2002). Autoinduction of the $o m p R$ response regulator by acid shock and control of the Salmonella enterica acid tolerance response. Mol. Microbiol. 44, 1235-1250.

Bang, I. S., Kim, B. H., Foster, J. W., and Park, Y. K. (2000). OmpR regulates the stationary-phase acid tolerance response of Salmonella enterica serovar Typhimurium. J. Bacteriol. 182, 2245-2252.

Baumler, A. J., Tsolis, R. M., van der Velden, A. W. M., Stojiljkovic, I., Anic, S., and Heffron, F. (1996). Identification of a new iron regulated locus of Salmonella typhi. Gene 183, 207-213.
Bernardini, M. L., Fontaine, A., and Sansonetti, P. (1990). The twocomponent regulatory system ompR-envZ controls the virulence of Shigella flexneri. J. Bacteriol. 172, 6274-6281.

Bottone, E. J. (1997). Yersinia enterocolitica: the charisma continues. Clin. Microbiol. Rev. 10, 257-276.

Brzostek, K., Brzóstkowska, M., Bukowska, I., Karwicka, E., and Raczkowska, A. (2007). OmpR negatively regulates expression of invasin in Yersinia enterocolitica. Microbiol. 153, 2416-2425.

Brzostek, K., Hrebenda, J., Benz, R., and Boos, W. (1989). The OmpC protein of Yersinia enterocolitica: purification and properties. Res. Microbiol. 140, 599-614.

Brzostek, K., and Raczkowska, A. (2003). The osmotic regulator OmpR is involved in the response of Yersinia enterocolitica O:9 to environmental stresses and survival within macrophages. FEMS Microbiol. Lett. 228, 265-271.

Brzostek, K., and Raczkowska, A. (2007). The YompC protein of Yersinia enterocolitica: molecular named RovM, a LysR-type regulator, has been shown to negatively modulate rovA expression in both enteropathogenic species (Heroven and Dersch, 2006). Furthermore, the Crs system has been found to affect expression of the rovA gene by regulating RovM synthesis (Heroven et al., 2008). In addition to H-NS, RovA and RovM, a fourth regulator of rovA, named LeuO, has also been identified. This LysR-like regulator appears to positively affect the expression of rovA in Y. enterocolitica (Lawrenz and Miller, 2007). Recently, RovA was identified as a putative protein thermometer. Thermal shifts from $26^{\circ} \mathrm{C}$ to $37^{\circ} \mathrm{C}$ probably lead to reversible conformational changes in RovA, which reduce its DNA-binding functions and render it more susceptible to proteolysis (Herbst et al., 2009).

In summary, our results indicate that OmpR in Y. enterocolitica serotype O9 directly influences inv expression via binding to the inv promoter, but not through modulation of rovA expression. In addition, phosphorylation of OmpR by acetyl-P appears to stimulate its binding ability. However, the mechanism by which phosphorylated OmpR represses the expression of inv remains unknown. Our findings raise the possibility that OmpR-P binding to the inv promoter could influence RovA interaction with two binding sites of different affinities located in this region.

\section{ACKNOWLEDGMENTS}

This work was supported by Polish Ministry of Science and Higher Education grant N303 009 32/0537 and Warsaw University grants BW 1720/7, 1720/56. We thank Dr. Mirosława Sokół for help with statistical analysis. and physiological characterization. Folia Microbiol. 52, 73-80.

Cai, S. J., and Inouye, M. (2002). EnvZ-OmpR interaction and osmoregulation in Escherichia coli. J. Biol. Chem. 277, 24155-24161.

Carlsson, K. E., Liu, J., Edqvist, P. J., and Francis, M. S. (2007). Influence of the Cpx extracytoplasmic-stressresponsive pathway on Yersinia sp.- eukaryotic cell contact. Infect. Immun. 75, 4386-4399.

Cathelyn, J. S., Crosby, S. D., Lathem, W. W., Goldman, W. E., and Miller, V. L. (2006). RovA, a global regulator of Yersinia pestis, specifically required for bubonic plague. Proc. Natl. Acad. Sci. U.S.A. 103, 13514-13519.

Cathelyn, J. S., Ellison, D. W. Hinchliffe, S. J., Wren, B. W., and Miller, V. L. (2007). The RovA regulons of Yersinia enterocolitica and Yersinia pestis are distinct: evidence that many RovA-regulated genes were acquired more recently than the core genome. Mol. Microbiol. 66, 189-205.

Dersch, P., and Isberg, R. (2000). An immunoglobin superfamily-like domain unique to the Yersinia pseudotuberculosis invasin protein is required for stimulation of bacterial uptake via integrin receptors. Infect. Immun. 68, 2930-2938.

Dorman, C. J., Chatfield, S., Higgins, C. F., Hayward, C., and Dougan, G. (1989). Characterization of porin and ompR mutants of a virulent strain of Salmonella typhimurium: ompR mutants are attenuated in vivo. Infect. Immun. 57, 2136-2140.

Dorrell, N., Li, S. R., Everest, P. H., Dougan, G., and Wren, B. W. (1998). Construction and characterisation of a Yersinia enterocolitica O:8 ompR mutant. FEMS Microbiol. Lett. 165, 145-151.

Ellison, D. W., Lawrenz, M. B., and Miller, V. L. (2004). Invasin and beyond: regulation of Yersinia virulence by RovA. Trends Microbiol. 12, 296-300.

Ellison, D. W., and Miller, V. L. (2006a). Regulation of virulence by members of the MarR/SlyA family. Curr. Opin. Microbiol. 9, 153-159.

Ellison, D. W., and Miller, V. L. (2006b). $\mathrm{H}-\mathrm{NS}$ represses inv transcription in Yersinia enterocolitica through 
competition with RovA and interaction with YmoA. J. Bacteriol. 188, 5101-5112.

Ellison, D. W., Young, B., Nelson, K., and Miller, V. L. (2003). YmoA negatively regulates expression of invasin from Yersinia enterocolitica. J. Bacteriol. 185, 7153-7159.

Flamez, C., Ricard, I., Arafah, S., Simonet, M., and Marceau, M. (2008). Phenotypic analysis of Yersinia pseudotuberculosis 32777 response regulator mutants: new insights into two-component system regulon plasticity in bacteria. Int. J. Med. Microbiol. 298, 193-207.

Forst, S. A., Delgado, J., Rampersaud, A., and Inouye, M. (1990). In vivo phosphorylation of $o m p R$, the transcription activator of the ompR and ompC genes in Escherichia coli. J. Bacteriol. 172, 3473-3477.

Forst, S. A., and Roberts, D. L. (1994). Signal transduction by the EnvZOmpR phosphotransfer system in bacteria. Res. Microbiol. 145, 363-373.

Gao, H., Zhang, Y., Han, Y., Yang, L., Liu, X., Guo, Z., et al. (2011). Phenotypic and transcriptional analysis of the osmotic regulator OmpR in Yersinia pestis. BMC Microbiol. 11:39. doi: 10.1186/1471-2180-11-39

Gibson, M. M., Ellis, E. M., GraemeCook, K. A., and Higgins, C. F. (1987). OmpR and EnvZ are pleiotropic regulatory proteins: positive regulation of the tripeptide permease (tppB) of Salmonella typhimurium. Mol. Gen. Genet. 207, 120-129.

Grutzkau, A., Hanski, C., Hahn, H., and Riecken, E. O. (1990). Involvement of $\mathrm{M}$ cells in the bacterial invasion of Peyer's patches: a common mechanism shared by Yersinia enterocolitica and other enteroinvasive bacteria. Gut 31, 1011-1015.

Herbst, K., Bujara, M., Heroven, A. K., Opitz, W., Weichert, M., Zimmermann, A., et al. (2009). Intrinsic thermal sensing controls proteolysis of Yersinia virulence regulator RovA. PLoS Pathog. 5:e1000435. doi: 10.1371/journal.ppat.1000435

Heroven, A. K., Böhme, K., Rohde, M., and Dersch, P. (2008). A Csrtype regulatory system, including small non-coding RNAs, regulates the global virulence regulator RovA of Yersinia pseudotuberculosis through RovM. Mol. Microbiol. 68, 1179-1195.
Heroven, A. K., and Dersch, P. (2006). RovM, a novel LysR-type regulator of the virulence activator gene $\operatorname{rov} A$, controls cell invasion, virulence and motility of Yersinia pseudotuberculosis. Mol. Microbiol. 62, 1469-1483.

Heroven, A. K., Nagel, G., Tran, H. J., Parr, S., and Dersch, P. (2004). RovA is autoregulated and antagonizes $\mathrm{H}$ NS-mediated silencing of invasin and rovA expression in Yersinia pseudotuberculosis. Mol. Microbiol. 53, 871-888.

Higashitani, A., Nishimura, Y., Hara, H., Aiba, H., Mizuno, T., and Horiuchi, K. (1993). Osmoregulation of the fatty acid receptor gene fadL in Escherichia coli. Mol. Gen. Genet. 240, 339-347.

Hoch, J. A., and Silhavy, T. J. (eds.). (1995). Two-Component Signal Transduction. Washington, DC: American Society for Microbiology Press.

Hu, Y., Lu, P., Wang, Y., Ding, L., Atkinson, S., and Chen, S. (2009a). OmpR positively regulates urease expression to enhance acid survival of Yersinia pseudotuberculosis. Microbiology 155, 2522-2531.

Hu, Y., Wang, Y., Ding, L., Lu, P., Atkinson, S., and Chen, S. (2009b). Positive regulation of $\mathrm{flhDC}$ expression by OmpR in Yersinia pseudotuberculosis. Microbiology 155, 3622-3631.

Huang, L., Tsui, P., and Freundlich, M. (1992). Positive and negative control of $o m p B$ transcription in Escherichia coli by cyclic AMP and the cyclic AMP receptor protein. J. Bacteriol. 174, 664-670.

Isberg, R. R., and Van Nhieu, G. T. (1995). The mechanism of phagocytic uptake promoted by invasinintegrin interaction. Trends Cell. Biol. 5, 120-124.

Jubelin, G., Vianney, A., Beloin, C., Ghigo, J. M., Lazzaroni, J. C., Lejeune, P., et al. (2005). CpxR/OmpR interplay regulates curli gene expression in response to osmolarity in Escherichia coli. J. Bacteriol. 187, 2038-2049.

Kenney, L. L. (2002). Structure/function relationships in OmpR and other winged-helix transcription factors. Curr. Opin. Microbiol. 5, 135-141.

Kinder, S. A., Badger, J. L., Bryant, G. O., Pepe, J. C., and Miller, V. L. (1993). Cloning of the YenI restriction endonuclease and methyltransferase from Yersinia enterocolitica serotype $\mathrm{O} 8$ and construction of a transformable $\mathrm{R}^{-} \mathrm{M}^{+}$mutant. Gene 136, 271-275.

Lan, C. Y., and Igo, M. M. (1998). Differential expression of the
OmpF and OmpC porin proteins in Escherichia coli K-12 depends upon the level of active OmpR. J. Bacteriol. 180, 171-174.

Lawrenz, M. B., and Miller, V. L. (2007). Comparative analysis of the regulation of rovA from the pathogenic Yersiniae. J. Bacteriol. 189, 5963-5975.

Lee, A. K., Detweiler, C. S., and Falkow, S. (2000). OmpR regulates the twocomponent system SsrA-SsrB in Salmonella pathogenicity island 2 . J. Bacteriol. 182, 771-781.

Liu, J., Obi, I. R., Thanikkal, E. J., Kieselbach, T., and Francis, M S. (2011). Phosphorylated CpxR Restricts Production of the RovA Global Regulator in Yersinia pseudotuberculosis. PLoS ONE 6:e23314. doi: 10.1371/journal.pone.0023314

Marceau, M. (2005). Transcriptional regulation in Yersinia: an update. Curr. Issues. Mol. Biol. 7, 151-177.

Matsubara, M., and Mizuno, T. (1999). EnvZ-independent phosphotransfer signaling pathway of the OmpR-mediated osmoregulatory expression of OmpC and OmpF in Escherichia coli. Biosci. Biotechnol. Biochem. 63, 408-414.

McCleary, W. R., and Stock, J. B. (1994). Acetyl phosphate and the activation of two-component response regulators. J. Biol. Chem. 269, 31567-31572.

Miller, J. H. (1972). Experiments in Molecular Genetics. Cold Spring Harbor, NY: Cold Spring Harbor Laboratory.

Nagel, G., Lahrz, A., and Dersch, P. (2001). Environmental control of invasin expression in Yersinia pseudotuberculosis is mediated by regulation of RovA, a transcriptional activator of the Sly/Hor family. Mol. Microbiol. 41, 1249-1269.

O'Loughlin, J. L., Spinner, J. L., Minnich, S. A., and Kobayashi, S. D. (2010). Yersinia pestis twocomponent gene regulatory systems promote survival in human neutrophils. Infect. Immun. 78, 773-782.

Pepe, J., and Miller, V. L. (1993). Yersinia enterocolitica invasin: a primary role in the initiation of infection. Proc. Natl. Acad. Sci. U.S.A. 90, 6473-6477.

Pepe, J. C., Badger, J. L., and Miller, V. L. (1994). Growth phase and low $\mathrm{pH}$ affect the thermal regulation of the Yersinia enterocolitica inv gene. Mol. Microbiol. 11, 123-135.

Qin, L., Cai, S., Zhu, Y., and Inouye, M. (2003). Cysteine-scanning analysis of the dimerization domain of EnvZ, an osmosensing histidine kinase. J. Bacteriol. 185, 3429-3435.
Raczkowska, A., Brzóstkowska, M., Kwiatek, A., Bielecki, J., and Brzostek, K. (2011a). Modulation of inv gene expression by the OmpR two-component response regulator protein of Yersinia enterocolitica. Folia Microbiol. 56, 313-319.

Raczkowska, A., Skorek, K., Bielecki, J., and Brzostek, K. (2011b). OmpR controls Yersinia enterocolitica motility by positive regulation of flhDC expression. Antonie Van Leeuwenhoek. 99, 381-394.

Raczkowska, A., Skorek, K., Brzóstkowska, M., Lasiñska, A., and Brzostek, K. (2011c). Pleiotropic effects of a Yersinia enterocolitica ompR mutation on adherent-invasive abilities and biofilm formation. FEMS Microbiol. Lett. 321, 43-49.

Revell, P. A., and Miller, V. L. (2000). A chromosomally encoded regulator is required for expression of the Yersinia enterocolitica inv gene and for virulence. Mol. Microbiol. 35, 677-685.

Russo, F. D., and Silhavy, T. J. (1991). EnvZ controls the concentration of phosphoryled OmpR to mediate osmoregulation of the porin genes. J. Mol. Biol. 222, 567-580.

Sambrook, J., Fritsch, E. F., and Maniatis, T. (1989). Molecular Cloning: A Laboratory Manual, 2nd Edn. Cold Spring Harbor, NY: Cold Spring Harbor Laboratory.

Shin, S., and Park, C. (1995). Modulation of flagellar expression in Escherichia coli by acetyl phosphate and the osmoregulator OmpR. J. Bacteriol. 177, 4696-4702. Simon, R., Priefer, U., and Puhler, A. (1983). A broad host range mobilization system for in vivo genetic engineering: transposon mutagenesis in gram negative bacteria. Bio/Technology 1, 784-791.

Stock, J. B., Ninfa, A. J., and Stock, A. M. (1989). Protein phosphorylation and regulation of adaptive responses in bacteria. Microbiol. Rev. 53, 450-490.

Straley, S. C., and Perry, R. D. (1995). Environmental modulation of gene expression and pathogenesis in Yersinia. Trends Microbiol. 3, 310-317.

Towbin, H., Staehelin, T., and Gordon, J. (1979). Electrophoretic transfer of proteins from polyacrylamide gels to nitrocellulose sheets: procedure and some applications. Proc. Natl. Acad. Sci. U.S.A. 76, 4335-4354.

Tran, H. J., Heroven, A. K., Winkler, L., Spreter, T., Beatrix, B., and Dersch, P. (2005). Analysis of RovA, a transcriptional regulator of Yersinia pseudotuberculosis virulence that 
acts through antirepression and direct transcriptional activation. J. Biol. Chem. 280, 42423-42432.

Trček, J., Fuchs, T. M., and Trülzsch, K. (2010). Analysis of Yersinia enterocolitica invasin expression in vitro and in vivo using a novel luxCDABE reporter system. Microbiology 156, 2734-2745.

Uliczka, F., Pisano, F., Schaake, J., Stolz, T., Rohde, M., Fruth, A., et al. (2011). Unique cell adhesion and invasion properties of Yersinia enterocolitica $\mathrm{O}: 3$, the most frequent cause of human yersiniosis. PLoS Pathog. 7:e1002117. doi: 10.1371/journal.ppat.1002117

Yoshida, T., Cai, S., and Inouye, M. (2002). Interaction of EnvZ, a sensory histidine kinase, with phosphorylated OmpR, the cognate response regulator. Mol. Microbiol. 46, 1283-1294.

Conflict of Interest Statement: The authors declare that the research was conducted in the absence of any commercial or financial relationships that could be construed as a potential conflict of interest.

Received: 20 August 2012; accepted: 19 November 2012; published online: 18 December 2012.

Citation: Brzóstkowska M, Raczkowska $A$ and Brzostek K (2012) OmpR, a response regulator of the twocomponent signal transduction pathway, influences inv gene expression in Yersinia enterocolitica O9. Front. Cell. Inf. Microbio. 2:153. doi: 10.3389/fcimb. 2012.00153

Copyright (c) 2012 Brzóstkowska, Raczkowska and Brzostek. This is an open-access article distributed under the terms of the Creative Commons Attribution License, which permits use, distribution and reproduction in other forums, provided the original authors and source are credited and subject to any copyright notices concerning any third-party graphics etc. 